Provided for non-commercial research and educational use only. Not for reproduction or distribution or commercial use.

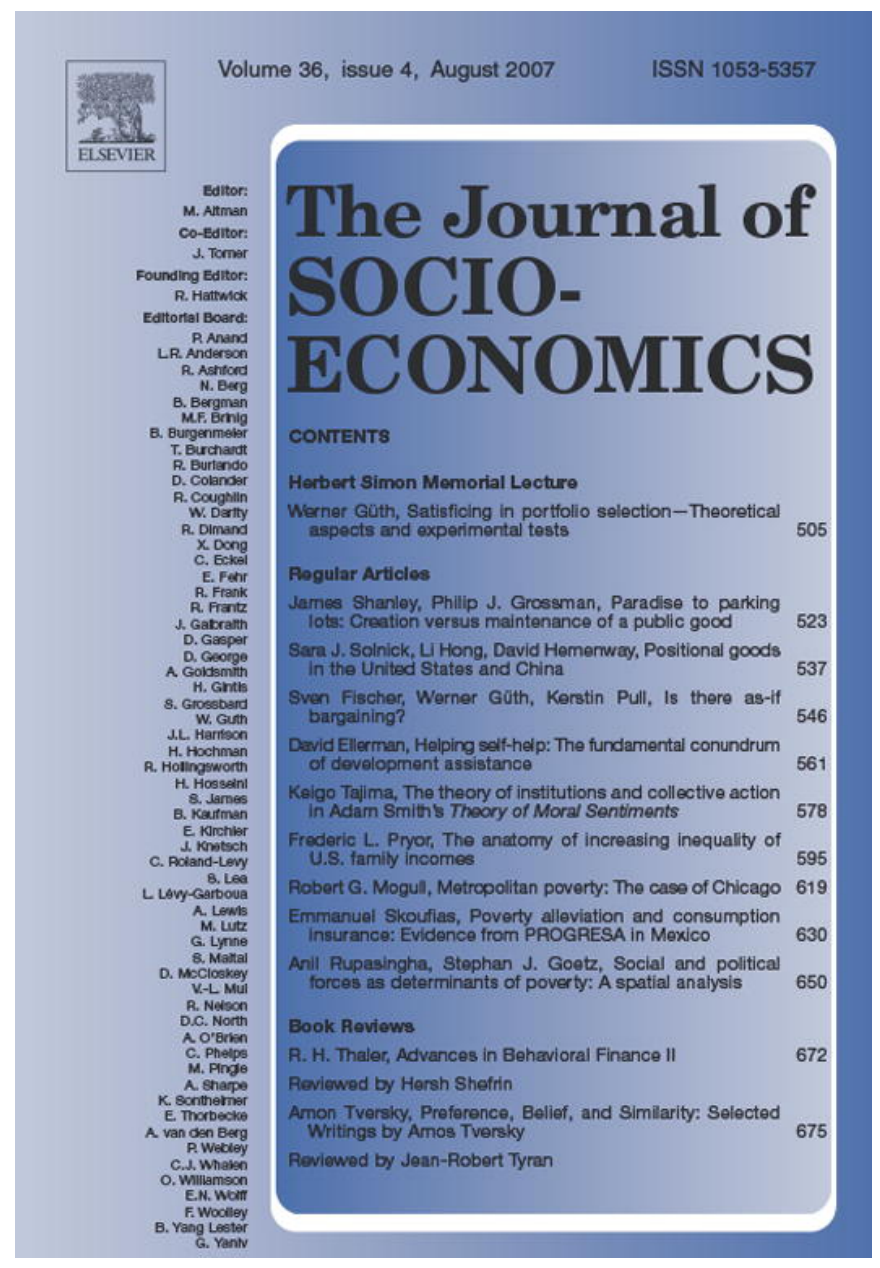

This article was originally published in a journal published by Elsevier, and the attached copy is provided by Elsevier for the author's benefit and for the benefit of the author's institution, for non-commercial research and educational use including without limitation use in instruction at your institution, sending it to specific colleagues that you know, and providing a copy to your institution's administrator.

All other uses, reproduction and distribution, including without limitation commercial reprints, selling or licensing copies or access,

or posting on open internet sites, your personal or institution's website or repository, are prohibited. For exceptions, permission may be sought for such use through Elsevier's permissions site at: 


\title{
Helping self-help: The fundamental conundrum of development assistance
}

\author{
David Ellerman \\ University of California at Riverside, 4044 Mt. Vernon Ave., Riverside, CA 92507, United States
}

\begin{abstract}
For more than half a century, there have been government programs and international organizations devoted to socially engineering development. As evidenced by the recent United Nation's Millennium Project report, surprisingly little has been learned as to why that mode of development assistance is ineffective. This paper takes an interdisciplinary approach to explaining the old idea that the best form of assistance is to help people help themselves but that this cannot be "engineered" as is amply evidenced by over a half-century of failures. There is a conundrum: how can the helpers supply help that furthers rather than overrides or undercuts the goal of the doers helping themselves? Otherwise, it is actually "unhelpful help." The overriding and undercutting forms of unhelpful help are analyzed and strategies for autonomy-respecting help are presented.
\end{abstract}

(C) 2007 Elsevier Inc. All rights reserved.

JEL classification: $\mathrm{O} 1$

Keywords: Development assistance; Community development; Autonomy

\section{Development assistance as helping people help themselves}

\subsection{Learning the lessons from the last half century}

It is only in the post-World War II era that there has been a concerted effort by the developed industrialized countries to offer technical and philanthropic assistance to the developing world. Overall, the official aid offered by developed countries and by the international agencies such as the World Bank has not been a resounding success. Where development has been most successful—as in East Asia - the official aid agencies have had little to do with it, and where the aid agencies have focused much of their assistance — as in Africa — that help has not been crowned with success. In

E-mail address: David@ellerman.org.

$U R L$ : www.ellerman.org.

1053-5357/\$ - see front matter (C) 2007 Elsevier Inc. All rights reserved.

doi:10.1016/j.socec.2006.12.014 
the course of the latter half of the 20th century, there have been many hard lessons. ${ }^{1}$ Unfortunately the major development assistance organizations have not learned these lessons.

In the early days of concerted development assistance (the 1940s and 1950s), development was seen as a huge socially engineered investment project. Outside agencies could help to finance the investments and to supply expertise. Impoverished people were lacking a number of specific "things" and once they had received those "things," they could then break out of their poverty traps, take control of their destinies, and achieve economic and social "lift-off" to development. The investments need to be planned and coordinated into a "big push" to finally break out of the otherwise self-reinforcing vicious circles of poverty and to "take off" on the path to development.

The principal intellectual critique to the big-push-investment-project approach to development was provided by Albert Hirschman in his The Strategy of Economic Development (1958) and in later writings. Reduced to a single idea, Hirschman's point was that if a country had the capacity to plan, coordinate, implement, and absorb the "big push," then it would hardly be an underdeveloped country in the first place.

Yet the development assistance industry, then and now, cannot "hear" any message about the ineffectiveness of what they are geared to do. Hence they keep on repeating the same basic ideas as if past failures were only due to insufficient resources invested, insufficient "bigness" to the "push," and the like. After nearly 40 years, the World Bank published a book, Investing in Development (Baum and Tolbert, 1985), which indicated that it still saw development as a large investment project. Now after 20 more years, the United Nations Millennium Project (directed by Jeffrey Sachs) has published its report which even has the same title, Investing in Development (2005). And it has the same message.

"The key to escaping the poverty trap is to raise the economy's capital stock to the point where the downward spiral ends and self-sustaining economic growth takes over. This requires a big push of basic investments between now and 2015 in public administration, human capital (nutrition, health, education), and key infrastructure (roads, electricity, ports, water and sanitation, accessible land for affordable housing, environmental management)." (UN Millennium Project, 2005, 19)

Change the dates, and this passage could have been right out of the big push literature of the 1940s and 1950s. After 60 years of failure for this social engineering approach to development assistance, what is one to do? Recommend rereading Hirschman? Here I will take the different approach of going back to the basics of the assistance or helping relationship. Over the ages, many social thinkers, educators, and philosophers have wrestled with the fundamental conundrum of helping self-help. Most external "help" actually overrides or undercuts the budding capacity for self-help and thus ends up being unhelpful. The big push schemes of the major development assistance agencies are for these reasons "unhelpful" on a grand scale.

\subsection{The helper-doer relationship}

It is a very old idea that the best form of assistance is to help people help themselves. We are all familiar with the ancient Chinese saying that if you give people fish, you feed them for a day, but if you teach them how to fish-or rather, if you help them learn how to fish-they can feed themselves for a lifetime.

\footnotetext{
${ }^{1}$ See Ellerman (2005) for more on international development assistance.
} 
First we need to establish some concepts and terminology; community assistance is analyzed as a relationship between those offering assistance in some form, the helper or helpers, and those receiving the assistance, the doer or doers. ${ }^{2}$ The helpers could be individuals, foundations, community development agencies, churches, charities, or nonprofit organizations, and the doers could be individuals, organizations or various levels of government in the disadvantaged communities. The relationship is the helper-doer relationship.

\subsection{The fundamental conundrum of assistance}

The assumed goal is transformation towards autonomous development on the part of the doers, with the doers helping themselves. The problem is how can the helpers supply help that actually furthers rather than overrides or undercuts the goal of the doers helping themselves? This is actually a paradox. If the helpers are supplying help that is important to the doers, then how can the doers really be helping themselves? Autonomy cannot be externally supplied. And if the doers are becoming autonomous, then what is the role of the external helpers? This paradox of supplying help to self-help, "assisted self-reliance"3 or assisted autonomy, is the fundamental conundrum of all helping relationships. Over the years, the debates about philanthropy and community assistance at home and abroad keep circling around and around this conundrum.

This conundrum is at the heart of the aid and philanthropy business, and I fear that fundamental progress depends on a very clear understanding of the contradiction. An appreciation of the conundrum goes back at least to the Taoist doctrine that the wise ruler rules in such a way that when the people prosper, they will say "We did it ourselves." It goes back to Socrates who deliberately refrained from giving out answers_ — claiming what we now call "Socratic ignorance" — and instead tried to indirectly (e.g., through questioning and irony) to spur a learning process so that when the doer learned, it would be the doer's own knowledge, not second-hand beliefs borrowed from an Expert. It goes back to the 19th century Danish philosopher, Søren Kierkegaard's theme (drawing explicitly on Socrates) that there is no objective or outside road to subjective or inside change. And it comes out in various ways today in the popular "self-help" literature such as Stephen Covey's theme (1990) about the difficulty in finding an outside-in road to inside-out change.

My aim is not to provide a new blueprint for development assistance but to point the way toward new strategies by trying to deepen the understanding of this basic conundrum and the kinds of "unhelpful help" that reduce the effectiveness of so much philanthropy and so many development assistance programs.

\subsection{Unhelpful help}

There are many strategies for assistance that may supply help in some form but actually do not help people help themselves. The forms of help that override or undercut people's capacity to help themselves will be called "unhelpful help."4

\footnotetext{
2 Doing includes thinking; "doer" is not juxtaposed to "thinker." Instead, the "doers" actively undertaking tasks are juxtaposed to the passive recipients of aid or assistance.

3 The phrase is from Uphoff et al. (1998). David Korten terms it the "central paradox of social development: the need to exert influence over people for the purpose of building their capacity to control their own lives" (1983, 220). See also Chapter 8 of Fisher (1993) on the "central paradox of social development."

4 For related notions, see Gronemeyer (1992) on "help (that) does not help" and the late Ivan Illich's notion of "counterproductivity" (1978).
} 
There are essentially two ways that the helper's will can supplant the doer's will to thwart autonomy and self-help:

(1) the helper, by professionally guided programs of social engineering, deliberately tries to impose his will on the doer;

(2) the helper, by benevolent aid, replaces the doer's will with her will, perhaps inadvertently.

"Override" or "undercut" are shorthand terms for these two conceptually distinct yin-andyang forms of unhelpful help (which may be combined, as when benevolence hides the desire to control).

\subsubsection{Unhelpful help \#1: social engineering}

The "overriding" form of unhelpful help is a type of social engineering. The helpers supply a set of instructions or programs for what the doers should be doing. They also offer motivation to follow this blueprint to override the doers' own motivations. If we use the metaphor of the doers as trying to work their way through a maze, then the helpers as social engineers perceive themselves as helicoptering over the maze, seeing the path to the goal, and supplying instructions (knowledge) along with carrots and sticks (incentives) to override the doers' own motivation and push the doers in the right direction.

The alternative to providing motivation is to give some resources (perhaps with a strong matching requirement) to enable the doers to undertake projects and programs that they were already motivated to do on their own. Fritz Schumacher put it well: "Perhaps the best-perhaps even the only-effective slogan for aid is: 'Find out what the people are trying to do and help them to do it better."' (Schumacher, 1964, 374)

\subsubsection{Unhelpful help \#2: benevolent aid}

The second form of unhelpful help occurs when the helper undercuts self-help by inadvertently supplying the motivation for the doer to be in or remain in a condition to receive help. One prominent example of this is long-term charitable relief. The world is awash with disaster situations that call for various forms of short-term charitable relief. The point is not to oppose these operations but to point out how charitable relief operates in the longer term to erode the doers' incentives to help themselves - and thus creates a dependency relationship. Charity corrupts; long-term charity corrupts long term.

All aid to adults based on the simple condition of needing aid risks displacing the causality. The working assumption is that the condition of needing aid was externally imposed (e.g., a natural disaster); the aid recipient shares no responsibility. But over the course of time, such aid tends to undermine this assumption as the aid in effect becomes a reward for staying in the state of needing aid, ${ }^{5}$ all of which risks creating dependency and learned helplessness. Thus relief becomes the unhelpful help that undermines self-help.

\subsection{The Scylla and Charybdis of community assistance}

The benevolent impulse to give charitable relief and the enlightened impulse to do social engineering are the Scylla and Charybdis of development assistance. Several major difficulties

\footnotetext{
5 See Murray (1984) or Ellwood (1988) on the "helping conundrums."
} 
lie in the path of adopting and implementing new strategies based on helping self-help. The first difficulty to be overcome is the simple recognition of the pitfalls of social programming on the one hand and of benevolent aid on the other hand.

Again and again, one finds well-meaning programs to "do X" being defended on the grounds that the doers should indeed do X (as if it were only the "what" and not the "how" that counts ${ }^{6}$ ). But there seems to be little or no real recognition that if the doers do X only to receive aid, then the motive will falsify the action, the reforms will not be well implemented, and the changes will not be sustained. Hence all the arguments about the beneficial nature of "doing X" miss the point.

And again and again, one finds benevolent aid being defended as doing good in the sense of "delivering resources to the poor" without any real recognition as to how this undercuts the incentives for developing self-reliance. All the arguments about the relief being "help" miss the point. It is an unhelpful form of help that in the longer term undercuts capacity-building and autonomous development.

The other major difficulty to be overcome is the gap between rhetoric and reality. The major development assistance agencies have long since learned to use the language of being against charity and imposed program engineering, and being in favor of helping people help themselves. But it is a remarkably subtle matter to overcome the basic conundrum and supply help in a way that does not override or undercut the development of the capacity for self-help. These points lead to some dos and don'ts.

\section{The first don't: do not override self-help capacity}

\subsection{The mental imagery of the expert intervention}

One major source of social engineering programs is the mental imagery of the professional helper who performs the surgical operation that restores the patient to health, a health that is thereafter self-sustaining. If the patient were able to cure himself, then the operation would not be necessary. But, according to this view, realities dictate that the helper must take control to ensure success and must supply the motivation for the doer to undergo the operation. Afterwards, with health restored, the doer can go his own way.

The late Ivan Illich (1972, 1976, 1978a, and particular "Disabling Professions" in 1978b) developed a general theory of how the "helping professions" (e.g., doctors, nurses, lawyers, psychologists, teachers, ministers, aid workers, and social workers in general), each with its professional associations, can provide counter-productive help that generates as many "needs" as it resolves, all the needs to be administered to by the "helpers." This theory has been further developed by McKnight (1995) using the notion of "disabling help." The helping professions do depend on neediness, disability, incapacity, and helplessness to make their living so they are in the paradoxical position of working to eliminate their own jobs — at least insofar as they actually try to help people help themselves. It should thus come as no surprise when again and again "helpers" use "giving-out-fish" strategies that tend to perpetuate the continuing need for helpers rather than "help the doers learn how to fish" strategies that would foster the doers' autonomy.

There are highly specific interventions-which might be called the "vaccinating children" (Dichter, 2003, 191) model—where the giving-out-fish direct methods might "work" in some

\footnotetext{
6 "All ironic observing is a matter of continually paying attention to the 'how,' whereas the honorable gentleman with whom the ironist has the honor of dealing pays attention only to the "what"' (Kierkegaard, 1992, 614).
} 
sense. The intervention is seen essentially as the helpers delivering a commodity or service to the more or less passive doers. To get it done, one just needs to enforce specific output-based conditions (e.g., aid based on "vaccinating X number of children"). Many practitioners in the helping business indulge in a refined form of self-delusion by flooding their minds with something like the vaccinating-children model as if it were typical rather than a very special case. For instance, "giving out mosquito nets" is a more recent simplistic idea of the "vaccinating-children" variety that can be constantly invoked as a model for development assistance (e.g., UN, 2005). Most real assistance work is concerned with the deeper questions of culture change, capacity-building, and sustainability where the "vaccinating-children" type of interventions are ineffective, if not counterproductive.

\subsection{The indirect approach}

The notion of autonomous development provides the clue to a new approach. Autonomous action is based on some inside-out, internal, or intrinsic motivation. Any action based on the externally supplied motivation of carrots and sticks is "heteronomous" (as philosophers would say). Any attempt to engineer autonomous action with external carrots or sticks would be selfdefeating; the means are inconsistent with the motive and thus defeat the end. Like shining a flashlight to get a better look at darkness, the approach contradicts the goal. ${ }^{7}$ This problem is often illustrated using the horse-to-water metaphor; externally engineered pressures can lead a horse to water, but that sort of motivation cannot make it drink. The whole idea of imposing professionally engineered change with supplied motivation might be termed the "direct" approach. That formulation then points to the alternative as being an "indirect" approach to helping, which implies not supplying motivation to the doers but finding the existing intrinsic motivation of the doers and offering help on that basis.

The indirect approach was well-developed both in educational theory and in broader social affairs by the American philosopher and educational theorist John Dewey (1859-1952):

We are even likely to take the influence of superior force for control, forgetting that while we may lead a horse to water we cannot make him drink; and that while we can shut a man up in a penitentiary we cannot make him penitent .... When we confuse a physical with an educative result, we always lose the chance of enlisting the person's own participating disposition in getting the result desired, and thereby of developing within him an intrinsic and persisting direction in the right way. (Dewey, 1916, 26-27)

Dewey also saw the general case for the indirect approach as the best way to help people help themselves:

The best kind of help to others, whenever possible, is indirect, and consists in such modifications of the conditions of life, of the general level of subsistence, as enables them independently to help themselves. (Dewey and Tufts, 1908, 390)

In terms of motivation, the indirect alternative does not involve a different set of carrots and sticks to motivate change, but instead comprises change that is based on inside-out intrinsic

\footnotetext{
7 To illustrate the self-defeating nature of using objective or outside-in approaches to subjective or inside-out change, Kierkegaard used stories of putting a magic cap on an elf (Kierkegaard, 1989, 12, 468) or putting special armor on the god Mars $(1992,174)$ to see how they looked when, in each case, the act made them invisible.
} 
motivation. The key is for the doers to embark on projects or programs motivated by themselves. This means that money cannot be the leading edge of the helpers' assistance-a truth that "moneymoving" assistance organizations are loath to admit. The direct link between money and motivation must be broken. Money can only play a role as a secondary or background enabler for what the doers independently want to do.

For an informal example, suppose one gives 100 dollars to one's daughter which could finance a 50 dollar bus fare to visit Uncle Henry and Aunt Louise during some college holidays. What if the grant was unrestricted and could have been spent on anything (and without "moral pressure")? If the money was still used for the bus fare then we could say that she was already motivated to make the visit and just needed the resources. The resources were only enabling, not imposing an outside-in directive. Otherwise, the grant with the proviso that she takes the trip would be supplying external motivation in addition to resources.

Developmental change cannot be bought, but where it is afoot on its own there will be costs of change that could be partly covered by development assistance agencies. Where, however, public assistance or philanthropic money takes the lead, it will be the magnet that sets all compasses wrong. It will distort the dynamics; it will sponsor a few more spins of the hamster-wheel of money-inspired programs; and it will end up essentially subsidizing the costs of not changing.

Since intrinsic motivation cannot be based on external carrots and sticks, the helpers cannot supply this motivation to the doers; they can only find it and help remove obstacles that might thwart it.

What about an approach of just responding to given local initiatives rather than trying to develop and drive the agenda? That is the operating mental model of many foundations and aid agencies; assume a "given" own-motivated project and then intervene to enable it to go forward. This can indeed work on day 1 , but not on day 2; motives are twisted over time. Once the word gets out that there is a large open checkbook in town, then all sorts of aid-seeking projects will be quickly generated and one will then no longer be responding to a given local initiative but with generating local pseudo-initiatives. To avoid that consequence, one needs to "sterilize" the announcement effect of the agency's aid to the first initiative and that brings us back to the more subtle indirect methods designed to foster self-help.

In the Men in Black movie, the protagonists use a "memory-eraser" instrument to blank the memories of alien encounters. Such an instrument would be useful to erase the memory of an encounter with an aid agency "from another world" and thus to restore the initial conditions where people undertake community-building projects for their own intrinsic reasons. Then an agency can again intervene to fund a genuine project rather than a money-seeking project. But lacking such an instrument, foundations and aid agencies spend much time trying to separate the genuine from the essentially money-seeking projects. And in a co-evolutionary process, the money-seeking projects evolve better and better mimicry to pretend to be genuine own-motivated projects. When the money-moving pressures on the side of the aid agencies meet the moneyseeking mimicry on the part of the aid-seekers, then there tends to evolve a tacit social contract or "norm" of mutual self-delusion to accommodate the needs satisfied on both sides by moving the money. Thus aid can go on and on being ineffective by sponsoring learned disability and aid addiction.

Ironically the best approach may be indirect where the checkbook is kept out of any direct interactions. One key to getting communities organized and helping themselves is often an outside community organizer, animator, or facilitator (or small team of such organizers). It is important that the organizer does not bring money. John McKnight (who developed a theory of disabling help) has gone on to describe how community organizers could be enabling by starting from the 
community capabilities, functionings, and "assets" to first see what people can do for themselves without significant external resources (McKnight, 1995 and Kretzmann and McKnight, 1993). ${ }^{8}$

\subsection{Separating program aid and policy advice}

In international development assistance, Albert Hirschman has harvested these lessons about separating program aid from policy advice about "doing the right thing."

Paradoxically, therefore, program aid is fully effective only when it does not achieve anything-when, that is, no quid pro quo (in the sense of a policy that would not have been undertaken in the absence of aid) is exacted as the price of aid. (Hirschman, 1971, 204)

Naturally, doubts and reservations are not voiced at the moment of the aid compact; hence the delusion on the part of the donor that there has been a full meeting of minds. But soon after virtue has been 'bought' through aid under these conditions, the reservations and resistances will find some expression - for example, through half-hearted implementation or sabotage of the agreed-to policies - and relations between donor and recipient will promptly deteriorate as a result. (205)

[I]t is our conviction that this picture of program aid as a catalyst for virtuous policies belongs to the realm of rhapsodic phantasy. (205)

[E]laborate arrangements should be made to divorce the exchange of opinions about suitable economic policies from the actual aid-giving process. (211)

Such irony! - the less the development advisor is "helpful" in the sense of giving them money now, the more the helper could be genuinely helpful in the long run.

There are other ways that an indirect approach might work. Look at the ways that the Highlander Folk School ${ }^{9}$ in Tennessee worked to foster community and labor organizing during the 1950s and 1960s in Appalachian communities and in the broader civil rights efforts in the South-see the autobiography (1998) of the founder, Myles Horton (1905-1990). In spite of the name "school", Highlander operated more as a place for community groups to come together to strategize, learn from each other, and consult with the staff's experience. For instance, Rosa Parks had been to a Highlander workshop shortly before the day when she held her seat on the Birmingham bus. And the Citizenship School Movement that spread spontaneously across the South to later feed the voting rights campaign in the Civil Rights Movement started with a Highlander project on the sea islands off the Carolinas. Highlander brought no money to help the people it helped, but it required money itself from various sources to keep operating.

Eugster (1966) tells her remarkable story of a union organizer turned housewife and then a volunteer "field educator" on her own initiative in a nearby Black community. The case exemplifies autonomy-respecting assistance as she constantly walked on the edge, catalyzing action in a community of which she was not a part while observing the limits of the autonomy-respecting helper role by withdrawing whenever it seemed that she was taking ownership or leadership or that people were only doing things to please her rather than for their own motives. It was a subtle time-consuming process that was full of pitfalls even when she brought no money. If she

\footnotetext{
${ }^{8}$ See the first Do below about starting from where people are.

${ }^{9}$ During the Civil Rights Movement, opponents sponsored billboards with a picture of Martin Luther King Jr. at a “communist training school." King as well as Rosa Parks, Ralph Abernathy, and Pete Seeger were attending Highlander's 25th anniversary celebration in 1957.
} 
had a large wealth or power differential with respect to the doers, then it would have been near impossible to prevent the overriding or undercutting forms of unhelpful help.

\subsection{Stop the teaching so that the learning can begin!}

There is much old wisdom about an indirect approach to social learning. Instead of claiming that the "answers" should be disseminated from expert-helper to counterpart-doer, Socrates displayed the humility of knowing that he did not know. He did not put learners in a passive role, but helped them to try actively to answer questions or resolve problems.

That real education aims at imparting knowledge rather than opinion, that knowledge cannot be handed over ready-made but has to be appropriated by the knower, that appropriation is possible only through one's own search, and that to make him aware of his ignorance is to start a man on the search for knowledge-these are the considerations that govern and determine the Socratic method of teaching. (Versényi, 1963, 117)

Indeed, the key to the indirect approach is for the helper as midwife to facilitate the doer taking the active role. As George Bernard Shaw put it: "If you teach a man anything he will never learn it" (1962, 174). José Ortega y Gasset suggested: "He who wants to teach a truth should place us in the position to discover it ourselves" $(1961,67)$. Or as Myles Horton maintained: "You don't just tell people something; you find a way to use situations to educate them so that they can learn to figure things out themselves" $(1998,122)$.

More on this theme has emerged from recent experience. Donald Schön has harvested many of the lessons from the War on Poverty in the 1960s. The default theory of social learning is that the helpers in the "center" make policies and design programs and then transmit the programs to the doers in the "periphery" for proper implementation.

[The standard approach] treats government as center, the rest of society as periphery. Central has responsibility for the formation of new policy and for its imposition on localities at the periphery. Central attempts to 'train' agencies at the periphery. In spite of the language of experimentation, government-initiated learning tends to be confined to efforts to induce localities to behave in conformity with central policy. (Schön, 1971, 177)

But close attention to the successes and failures in the War on Poverty and many other examples shows that social learning can take place in a decentralized bottom-up manner with only centralized coordination. Schön described a process between the government and the periphery of local units trying to carry out a certain social reform.

Government cannot play the role of 'experimenter for the nation', seeking first to identify the correct solution, then to train society at large in its adaptation. The opportunity for learning is primarily in discovered systems at the periphery, not in the nexus of official policies at the center. Central's role is to detect significant shifts at the periphery, to pay explicit attention to the emergence of ideas in good currency, and to derive themes of policy by induction. The movement of learning is as much from periphery to periphery, or periphery to center, as from center to periphery. Central comes to function as facilitator of society's learning, rather than as society's trainer. (Schön, 1971, 177-178)

Social learning is often very different from laboratory learning. Novel complexity, genuine uncertainty, conflict of values, unique circumstances, and structural instabilities mitigate against "laboratory conditions" for discovery and learning. Decentralized parallel experimentation with 
centrally sponsored framing and quality benchmarking followed by peer-to-peer cross-learning in the periphery is a more appropriate model than research at a central facility followed by the teaching-dissemination of the results. ${ }^{10}$

\section{The second don't: do not undercut self-help capacity with benevolent aid}

\subsection{John Dewey on "Oppressive Benevolence"}

We saw previously that John Dewey criticized the controlling engineering approach to help as not promoting people's capacity to help themselves. Dewey also criticized "oppressive benevolence" as undercutting that capacity development. ${ }^{11} \mathrm{He}$ was inspired in this by Chicago reformer Jane Addams (1860-1935). Prior to being the first American woman to win the Nobel Peace Prize in 1931, Jane Addams was best known as the leader of the settlement house movement in America (see Lasch, 1965). In contrast to the "charity ladies" of late 19th century America, she lived in a settlement house, Chicago's Hull House, in an impoverished area and worked directly with the community. The epitome of industrial benevolence in her day was George Pullman who planned and built a company town for "his workers" generously endowed with a gymnasium, libraries, schools, and parks. Workers were required to live there and pay rent to the Pullman Company. When wages were slashed during a depression but rents kept the same, the workers went on strike. Pullman was flummoxed that his workers could show so little gratitude after all that he had done for them.

Jane Addams wrote a critique of Pullman's paternalism towards "his" workers in her essay "A Modern Lear" (Addams, 1965), an essay that Dewey called "one of the greatest things I ever read both as to its form and its ethical philosophy" (quoted by Christopher Lasch in Addams, 1965, 176).

As its title suggests, Addams's essay was based on an extended analogy between the relationship between King Lear and his daughter Cordelia and that of Pullman and his workers. Like Lear, Addams suggested, Pullman exercised a self-serving benevolence in which he defined the needs of those who were the objects of this benevolence in terms of his own desires and interests. Pullman built a model company town, providing his workers with what he took to be all the necessities of life. Like Lear, however, he ignored one of the most important human needs, the need for autonomy. (Westbrook, 1991, 89)

Christopher Lasch developed some of the same ideas in his contrast of the "ethic of respect" with the "ethic of compassion" (Lasch, 1995). According to Lasch's colleague, Robert Westbrook, Dewey held that:

(S)elf-realization was a do-it-yourself project; it was not an end that one individual could give to or force on another. The truly moral man was, to be sure, interested in the welfare of others-such an interest was essential to his own self-realization-but a true interest in others lay in a desire to expand their autonomous activity, not in the desire to render them the dependent objects of charitable benevolence. (Westbrook, 1991, 46-47)

\footnotetext{
$\overline{10 \text { Rogers }}$ (1983) described a similar process of decentralized social learning involved in China finding reforms in its evolution towards a market economy.

11 Dichter $(2003,98)$ quotes from Charles Dickens' Bleak House on "rapacious benevolence."
} 
An incapacity for beneficial self-activity was assumed to be part of the condition of the poor, so reformers would treat them accordingly.

The conception of conferring the good upon others, or at least attaining it for them, which is our inheritance from the aristocratic civilization of the past, is so deeply embodied in religious, political, and charitable institutions and in moral teachings, that it dies hard. Many a man, feeling himself justified by the social character of his ultimate aim (it may be economic, or educational, or political), is genuinely confused or exasperated by the increasing antagonism and resentment which he evokes, because he has not enlisted in his pursuit of the "common" end the freely cooperative activities of others. (Dewey and Tufts, 1908, 303-304)

Thus community assistance as benevolent aid does not help people help themselves and it may even lead to antagonism and resentment-all of which is baffling to those who derive moral satisfaction from doing good and making others happy.

To "make others happy" except through liberating their powers and engaging them in activities that enlarge the meaning of life is to harm them and to indulge ourselves under cover of exercising a special virtue .... To foster conditions that widen the horizon of others and give them command of their own powers, so that they can find their own happiness in their own fashion, is the way of "social" action. Otherwise the prayer of a freeman would be to be left alone, and to be delivered, above all, from "reformers" and "kind" people. (Dewey, 1957, 270)

In a similar vein, David Thoreau noted, "If I knew for a certainty that a man was coming to my house with the conscious design of doing me good, I should run for fear that I should have some of his good done to me" (quoted in Carmen, 1996, 47; and in Gronemeyer, 1992, 53).

\subsection{Relief assistance as generalized moral hazard}

The first Don't deals with program engineering as a form of unhelpful help that overrides any self-help capacity in order to get the doers to "do the right thing." The second Don't concerns benevolent aid that, unless very temporary, will tend to undermine the capacity for self-help. Sometimes aid is sought because of a self-perceived lack of efficacy. Aid granted out of benevolence, even without carrots and sticks, has the adverse effect of reinforcing the lack of self-confidence and doubts about one's own efficacy. Eleemosynary aid to relieve the symptoms of poverty may create a situation of moral hazard that weakens reform incentives and attenuates efforts for positive change to eliminate poverty (see Maren, 1997). Such aid "tends to render others dependent, and thus contradicts its own professed aim: the helping of others" (Dewey and Tufts, 1908, 387). The two Don'ts are interrelated when dependency-creating aid leaves the doers vulnerable to more social engineering control as well as more charity in a vicious circle that drives them away from autonomous development. ${ }^{12}$

Moral hazard refers to the phenomenon where excessive insurance relieves the insured from taking normal precautions so risky behavior might be increased. The phrase is applied generally to opportunistic actions undertaken because some arrangement has relieved the doers from bearing

\footnotetext{
12 See the "shifting the burden" from the would-be doers to the helper as the "generic dynamics of addiction" in Senge (1990, 104-113).
} 
the full responsibility for their actions. Benevolent help softens the incentives for people to help themselves.

In the insurance example, the limit case of no insurance (which means complete self-insurance) certainly solves the problem of moral hazard since the individual then has a full incentive to take precautions to prevent accidents. Yet the no-insurance option forgoes the benefits of insurance. There is no first-best solution of complete insurance without moral hazard, but there are partial solutions in the form of co-payments and deductibles so that the insured party retains some risk and thus some incentive to take normal precautions.

In a similar manner, the conservative approach of no assistance could be seen as the "tough love" limit case. It certainly solves the problem of softened incentives for self-help, but it foregoes more subtle forms of positive assistance that might be compatible with autonomy. The idea of co-payments carries over to the idea of non-trivial matching funds from the doers as a commitment mechanism to show that they are dedicated on their own account to the programs. The idea of deductibles carries over to the concept of second-stage funding, where the doers show commitment by funding the first stage of a program on their own.

I mentioned at the outset that the post-WWII effort for international development was one source of hard lessons about unhelpful help. This moral hazard analysis suggests the possibility that the post-World War II development assistance has created a massive generalized moral hazard problem. Among development economists, Bauer $(1976$; 1981) has developed these arguments about aid with particular force. Easterly (2001) has summarized the empirical results that, on the whole, document the lack of success in the last half century of development assistance based on various combinations of social engineering and benevolent aid. After a lifetime of working in development assistance NGOs, Dichter (2003) arrives at similar conclusions.

The often-cited bright spot is the Marshall Plan, which, in many ways, provided a model for later development efforts. Yet it also contained the seeds of moral hazard. Robert Marjolin, the French architect of the Marshall Plan, noted in a 1952 memo that American aid continuing over a longer term could have precisely that effect:

Although American aid has been a necessary remedy over a period, and will continue to be for a time, one is bound to acknowledge that in the long run it has had dangerous psychological and political effects .... It is making more difficult the task of the governments of Western Europe trying to bring about a thorough economic and financial rehabilitation. The idea that it is always possible to call on American aid, that here is the ever-present cure for external payments deficits, is a factor destructive of willpower. It is difficult to hope that, while this recourse continues to exist, the nations of Western Europe will apply, for a sufficient length of time, the courageous economic and financial policy that will enable them to meet their needs from their own resources without the contribution of external aid. (quoted in Marjolin, 1989, 241)

However, the demands of the Korean War and the lack of a permanent aid bureaucracy resulted in the winding down of American aid. If the industrial countries of Western Europe faced moral hazard problems in the short-lived Marshall Plan, one can only begin to fathom the extent of the moral hazard problem in developing countries today that face well-established professional aid-providers in the developed countries who constantly reinvent ways to move the money.

Money is a mixed blessing-to the extent that it is a blessing at all in assistance at home or abroad. As long as money continues to be the leading edge of assistance, then the problems of moral hazard will only be compounded. One sees the evidence every day in calls by leaders of the aid business to address this or that development problem with billions of dollars more in 
funding-rather than undertaking the difficult and subtle reforms for a more effective approach where money has a background role.

\section{The two dos}

\subsection{The first do: start from where the doers are}

The via negativa of the two Don'ts needs to be supplemented by two Dos that can help guide a more autonomy-respecting approach to development assistance. To be transformative, a process of change must start from and engage with the present endowment of institutions. Otherwise, the process will only create an overlay of new behaviors that is not sustainable (without continual bribes).

Yet this is a common error. Reformers oriented towards utopian social engineering (see Popper, 1962) aim to wipe the slate clean in order to install a set of ideal institutions. Any attempt to transform the current flawed, retrograde or even evil institutions is viewed as only staining or polluting the change process. On the international scene, we saw this attitude in the transitional economies such as Russia. Institutional shock therapy was supposed to make a once and for all "leap over the chasm" to leave the old corrupt institutions on one side and to land on the other side with bright shiny new institutions embodied in laws designed by outside experts. But as the Chicago community organizer, Saul Alinsky, emphasized, people "need a bridge to cross from their own experience to a new way" (Alinsky, 1971, xxi). Russia failed to make the leap and now it will take the country much longer to climb out of the chasm than it would have taken if a bridge over the chasm had been built step by step.

Similar considerations support the argument for an evolutionary and incremental strategy in poor communities.

The primary causes of extreme poverty are immaterial, they lie in certain deficiencies in education, organization and discipline .... Here lies the reason why development cannot be an act of creation, why it cannot be ordered, bought, comprehensively planned: why it requires a process of evolution. Education does not "jump"; it is a gradual process of great subtlety. Organization does not "jump"; it must gradually evolve to fit changing circumstances. And much the same goes for discipline. All three must evolve step by step, and the foremost task of development policy must be to speed this evolution. (Schumacher, 1973, 168-169)

Given a choice between helpers using the momentum of bottom-up involvement in "flawed" reforms and the top-down social engineering of "model" institutions, the start-from-where-thedoers-are principle (the first Do) argues for the former. Applied to technical interventions, it would be better for the helpers to train local doers to do the job-even if locals do it poorly at first, so long as there is a learning mechanism - than for the external helpers to "do the job right" but with little or no local capacity-building. Sometimes the best form of training is for the helper to broker horizontal or peer-to-peer learning between the doers and those who have already successfully done a job under similar circumstances.

\subsection{The second do: see the world through the doers' eyes}

If a social engineer could perform an "institutional lobotomy" to erase present institutional habits, then development advice would not need to be tailored to present circumstances. Generic 
advice would suffice; one message would fit all blank slates. But failing that, it is necessary to acquire a deeper knowledge of the present institutions. This is done by, in effect, learning to see the world through the eyes of the leaders and people in a community. "The change agent must psychologically zip him or herself into the clients' skins, and see their situation through their eyes" (Rogers, 1983, 316).

An interaction between teacher and learner that is compatible with autonomy requires that the teacher have an empathetic understanding with the student. If the teacher can understand the learning experience of the student, then the teacher can use his or her knowledge to help the student. This help does not take the form of telling the student the answer or solution, but of offering advice or guidance, perhaps away from a dead-end path, to assist the student in the active appropriation of knowledge. The teacher, according to Dewey's learner-centered pedagogy, must be able to see the world through the eyes of the students and within the limits of their experience, and at the same time apply the adult's viewpoint to offer guideposts. ${ }^{13}$ Similarly, in Carl Rogers' notion of client-centered therapy (1951), the counselor needs to enter the "internal frame of reference of the client" in order to give assistance that respects and relies upon the actual capacity of the person. ${ }^{14}$ Rogers quotes at length from a 1944 memo by Clifford Shaw, a sociologist working on problems of social disorganization and delinquency, about experience in a Chicago-area community project.

[A]ttempts to produce these changes for the community by means of ready made institutions and programs planned, developed, financed, and managed by persons outside the community are not likely to meet with any more success in the future than they have in the past. This procedure is psychologically unsound because it places the residents of the community in an inferior position and implies serious reservations with regard to their capacities and interest in their own welfare. What is equally important is that it neglects the greatest of all assets in any community, namely the talents, energies and other human resources of the people themselves .... What is necessary, we believe, is the organization and encouragement of social self-help on a cooperative basis. (Shaw, 1944; quoted in Rogers, 1951, 59)

This Chicago tradition of community organizing was developed further by Saul Alinsky (1909-1972) — the young Alinsky once worked in one of Shaw's projects-and more recently by John McKnight and his colleagues (see Kretzmann and McKnight, 1993). Alinsky's methods were based on his deep understanding of the helping self-help conundrum. He was a caustic critic (e.g., Alinsky, 1965) of the top-down and professionally programmed nature of the War on Poverty. In Daniel Patrick Moynihan's postmortem on the War on Poverty, he noted that Alinsky's “near to perfect" prognosis should have been taken to heart but was largely ignored. (Moynihan, 1969,

\footnotetext{
13 "[The teacher] does not give knowledge. Knowledge cannot be given. If you ask me a question all I can do in my reply is to try to put into words a part of my experience. But you get only the words, not the experience. To make meaning out of my words, you must use your own experience. ... But to the extent that you do share some of my experience, then by talking about my experience, by throwing a light on part of it, I may reveal to you something in your experience that you had not seen before, or help you to see it in a new way, to make, in David Hawkins's words, 'transitions and consolidations." (Holt, 1976, 85) The referenced passage by Hawkins is: "The teacher offers the learner some kind of loan of himself or herself, some kind of auxiliary equipment which will enable the learner to make transitions and consolidations he could not otherwise have made. And if this equipment is of the kind to be itself internalized, the learner not only learns, but begins, in the process, to be his own teacher-and that is how the loan is repaid ..." (quoted in Holt, 1976, 60; from Hawkins, 1973 and reprinted in Hawkins, 2000, 44).

14 Maurice Friedman emphasizes the importance of seeing through the eyes of the other in Martin Buber's notion of dialogue. "The essential element of genuine dialogue ... is 'seeing the other' or "experiencing the other side", (Friedman, 1960, 87).
} 
187; see Horwitt, 1989, 519) Cesar Chavez (1927-1993) started his organizing career working as an Alinsky organizer along with Fred Ross for 10 years (1953-1962) setting up Community Service Organizations in California before leaving to start the United Farm Workers Union.

In describing the process of an aid agency trying to help a developing country, Albert Hirschman recommends a process of familiarization - of walking in their shoes and looking through their eyes at the array of problems facing the country.

Little by little, after getting committed and "seeing," that is, learning about the country's problems, some hypotheses should emerge about the sequence in which a country is likely to attack successfully the multifarious obstacles. In the search for the best hypothesis, those who administer aid programs should use what Dr. Carl Rogers, the psychotherapist, calls "client-centered therapy." (Hirschman, 1971, 185)

How does the helper find out about the doers' world? One way is through Paulo Freire's notion of dialogue. In the non-dialogical approach to education, the teacher determines the appropriate messages to be delivered or "deposited" in the students, as money is deposited in a bank. Instead of ready-made best-practice recipes, Freire, like Dewey, saw the educational mission as based on posing problems, particularly those stemming from the learners' world:

In contrast with the anti-dialogical and non-communicative "deposits" of the banking method of education, the program content of the problem-posing method-dialogical par excellence-is constituted and organized by the students' view of the world, where their own generative themes are found. (Freire, 1970, 101)

For instance, in the first Citizenship School started by the Highlander School, the literacy pedagogy was described by one of the first teachers: "They tell me a story, a story which I write down, then they learn to read the story. It's their story in their words, and they are interested because it's theirs." (quoted in Horton, 1998, 103)

\subsection{Conclusion: the two paths}

After over a half-century of official development and anti-poverty assistance at home and abroad, we still find ourselves wandering in a dark wood. But starting from the fundamental conundrum of helping people to help themselves, it is becoming clear that there are two divergent paths. The well-worn path is the direct approach of conventional money-based and program-driven aid. If the goal is to help the doers of development to help themselves, then I have argued that the direct path tends to override (with programmed aid) or undercut (with benevolent aid) the doers' capacity for self-help.

Perhaps it is time to consider the less-trodden path of the indirect approach, which emphasizes forms of assistance based on respect for the autonomy of the doers. Initial steps on the indirect path were described with the two Dos: start from where the doers are and see the world through their eyes. Perhaps it would be useful to have a third Do as an overall description of the indirect approach: respect the autonomy of the doers.

On the direct path, the helper helps the doers by supplying distorted motivation to get the doers to do what the helpers take as "the right thing." On the indirect path, which respects autonomy, the helper helps the doers to help themselves by reducing obstacles and by supplying not motivation but perhaps some resources to enable the doers to do what the doers were already motivated to do themselves. On the knowledge side, the helper who respects autonomy supplies not answers but 
helps in a Socratic manner to build learning capacity that allows the doers to learn from whatever source and to learn whatever lessons in a self-directed learning process.

Direct methods can help others, but they cannot help others to help themselves. That requires autonomy-respecting indirect methods on the part of the helpers and autonomous self-activity on the part of the doers. Doers need not only to participate but also to be in the driver's seat in order to make their actions and learnings their own. It is the psychological version of the old principle that people have a natural ownership of the fruits of their own labor. The helpers can use indirect and enabling approaches to provide background assistance. But the doers have to take the initiative and then keep it from being overridden or undercut by external aid. And then they will be the doers of their own development.

\section{References}

Addams, J., 1965. A modern Lear. In: Lasch, C. (Ed.), The Social Thought of Jane Addams. Bobbs-Merrill, Indianapolis, pp. 105-123.

Alinsky, S., 1965. War on poverty—political pornography. Journal of Social Issues XXI (1 (January)), 41-47.

Alinsky, S., 1971. Rules for Radicals. Vintage, New York.

Bauer, P., 1976. Dissent on Development. Harvard University Press, Cambridge.

Bauer, P., 1981. Equality, the Third World, and Economic Delusion. Harvard, Cambridge.

Baum, W.C., Tolbert, S.M., 1985. Investing in Development: Lessons of World Bank Experience. Oxford University Press for the World Bank, Washington, DC.

Carmen, Raff, 1996. Autonomous Development. Zed Books, London.

Covey, Stephen, 1990. The Seven Habits of Highly Effective People. Simon \& Schuster, New York.

Dewey, J., 1916. Democracy and Education. Free Press, New York.

Dewey, J., 1957. Human Nature and Conduct: An Introduction to Social Psychology. Modern Library, New York.

Dewey, J., Tufts, J., 1908. Ethics. Henry Holt, New York.

Dichter, T., 2003. Despite Good Intentions: Why Development Assistance to the Third World has Failed. University of Massachusetts Press, Amherst MA.

Easterly, W., 2001. The Elusive Quest for Growth: Economists' Adventures and Misadventures in the Tropics. MIT Press, Cambridge.

Ellerman, D., 2005. Helping People Help Themselves: From the World Bank to an Alternative Philosophy of Development Assistance. University of Michigan Press, Ann Arbor.

Ellwood, D., 1988. Poor Support: Poverty in the American Family. Basic Books, New York.

Eugster, C., 1966. Field education in west heights: equipping a deprived community to help itself. In: Arthur, S. (Ed.), Sociology in Action. Dorsey Press, Homewood, IL, pp. 208-225 (Originally published in: Human Organization, Fall 1964).

Fisher, J., 1993. The Road From Rio: Sustainable Development and the Nongovernmental Movement in the Third World. Praeger, Westport.

Freire, Paulo, 1970. Pedagogy of the Oppressed. Continuum, New York.

Friedman, Maurice, 1960. Martin Buber: The Life of Dialogue. Harper Torch books, New York.

Gronemeyer, M., 1992. Helping. In: Wolfgang, S. (Ed.), The Development Dictionary: A Guide to Knowledge as Power. Zed Books, London, pp. 51-69.

Hawkins, D., 1973. What it means to teach. Teachers' College Record 75 (1), 7-16.

Hawkins, D., 2000. The Roots of Literacy. University Press of Colorado, Boulder.

Hirschman, A.O., 1958. The Strategy of Economic Development. Yale University Press, New Haven.

Hirschman, Albert O., 1971. A Bias for Hope: Essays on Development and Latin America. Yale University Press, New Haven.

Holt, John, 1976. Instead of Education: Ways to Help People Do Things Better. Delta, New York.

Horton, M., with Judith and Herbert Kohl, 1998. The Long Haul: An Autobiography. New York: Teachers College Press. Horwitt, S.D., 1989. Let Them Call Me Rebel: Saul Alinsky-His Life and Legacy. Vintage Books, New York.

Illich, I., 1972. Deschooling Society. Harper \& Row, New York.

Illich, Ivan, 1976. Medical Nemesis: The Expropriation of Health. Pantheon, New York.

Illich, I., 1978a. Toward a History of Needs. Pantheon Books, New York. 
Illich, I., 1978b. The Right to Useful Unemployment and Its Professional Enemies. Marion Boyars, London.

Kierkegaard, S., 1989. The Concept of Irony with Continual Reference to Socrates. edited and translated by Howard and Edna Hong. Princeton: Princeton University Press.

Kierkegaard, 1992. Concluding Unscientific Postscript to Philosophical Fragments, edited and translated by Howard and Edna Hong. Princeton: Princeton University Press.

Korten, David C., 1983. Social development: putting people first. In: Korten, D., Alfonso, F. (Eds.), Bureaucracy and the Poor: Closing the Gap. Kumarian, West Hartford, pp. 201-221.

Kretzmann, J.P., McKnight, J.L., 1993. Building Communities from the Inside Out: A Path Toward Finding and Mobilizing a Community's Assets. Institute for Policy Research, Evanston, IL.

Lasch, C. (Ed.), 1965. The Social Thought of Jane Addams. Bobbs-Merrill, Indianapolis.

Lasch, C., 1995. The Revolt of the Elites and the Betrayal of Democracy. Norton, New York.

Maren, Michael, 1997. The Road to Hell: The Ravaging Effects of Foreign Aid and International Charity. Free Press, New York.

Marjolin, R., 1989. In: Hall, W. (Trans.), Architect of European Unity: Memoirs 1911-1986. Weidenfeld and Nicolson, London.

McKnight, J., 1995. The Careless Society: Community and Its Counterfeits. Basic Books, New York.

Moynihan, D.P., 1969. Maximum Feasible Misunderstanding. The Free Press, New York.

Murray, C., 1984. Losing Ground: American Social Policy 1959-1980. Basic, New York.

Ortega y Gasset, J., 1961. Meditations on Quixote. Norton, New York.

Popper, K., 1962. The Open Society and Its Enemies: The High Tide of Prophecy: Hegel, Marx, and the Aftermath. Harper and Row, New York.

Rogers, C.R., 1951. Client-Centered Therapy. Houghton Mifflin, Boston.

Rogers, E., 1983. Diffusion of Innovations, third ed. Free Press, New York.

Schön, D.A., 1971. Beyond the Stable State. Norton, New York.

Schumacher, E.F., 1964. A humanistic guide to foreign aid. In: Novack, D., Lekachman, R. (Eds.), Development and Society. St. Martin's Press, New York, pp. 364-374.

Schumacher, E.F., 1973. Small is Beautiful: Economics As If People Mattered. Harper and Row, New York.

Senge, 1990. The Fifth Discipline: The Art and Practice of the Learning Organization. Currency Doubleday, New York.

Shaw, Clifford R., 1944. Memorandum submitted to the Board of Directors of the Chicago Area Project. Chicago Area Project. Mimeo, Chicago.

Shaw, George Bernard, 1962. The Wit and Wisdom of Bernard Shaw. Collier, New York.

UN Millennium Project, 2005. Investing in Development: A Practical Plan to Achieve the Millennium Development Goals. United Nations, New York.

Uphoff, N., Esman, M., Krishna, A., 1998. Reasons for Success: Learning from Instructive Experiences in Rural Development. Kumarian Press, West Hartford.

Versényi, Laszlo, 1963. Socratic Humanism. Yale University Press, New Haven.

Westbrook, R., 1991. John Dewey and American Democracy. Cornell University Press, Ithaca. 